\title{
A survey on parasites infecting mullets from Egypt and Libya
}

\author{
Dayhoum A.H. Al-Bassel ${ }^{1}$ and Abdel-Nasser A Hussein ${ }^{2}$ \\ 1- Zoology Department, Faculty of Science Fayoum University, Egypt \\ 2- Zoology Department, Faculty of Science, South Valley University, Qena, Egypt \\ Corrsponding author : dayhoum1@yahoo.com
}

\begin{abstract}
Two different localities were selected for the present investigation. Generally, out of 200 Mugil cephalus individuals examined, 63 (31.5\%) were found to be infected. Out of 119 M. cephalus, 44 (36.9\%) collected from Lake Qarun at Fayoum in Egypt were found infected. On the other hand, out of 81 M. cephalus, 19 (23.45\%) collected from Missurata fish market in Libya were found infected. The collected parasites from Egyptian specimens were Trematoda, Acanthocephala, Trichodina and Myxosporea. The incidences of infection were $88.6 \%, 27.2 \%, 95.5 \%$ and $27.3 \%$, respectively. Parasites of the Egyptian mullets includes: 4 species of trematoda (Haplosplanchnus caudatus, $H$. pachysomus, Lecithobotrys putrescens and Dicrogaster contractus); one species of Acanthocephala (Neoechinorhynchus sp.); three species of Trichodina (Trichodina lepsii, T. puytoraci and T. batala) and one species of Myxosporedia (Myxobolus sp.). It is worth mentioned that protozoan infections were restricted in Egyptian mullets. On the other hand, out of $81 \mathrm{M}$. cephalus, $19(23.45 \%)$ collected from Missurata were found infected by two genera of trematodes (Vitellibaculum girelia and Lecithocladium exisum).
\end{abstract}

Key Words: Review, Parasites, Mullets, Iincidence of infection, Egypt, Libya

\section{INTRODUCTION}

Two different saline waters, Lake Qarun in Egypt and coastal water of the Mediterranean Sea near Missurata in Libya were selected for the present study. Lake Qarun is the third largest lake in Egypt and the second most famous one after Lake Nasser in the Southern part of Egypt. It lies some 45 meters below sea level and occupies the lowest, northern section of the Fayoum depression. Lake Qarun has a surface area of 214 square kilometers. It has a maximum depth of just over 8 meters and a volume of 800 million cubic meters. It is $42 \mathrm{~km}$ long and $9 \mathrm{~km}$ wide at its broadest point (Meshal, 1973).

The Mediterranean Sea is a semi-enclosed Sea and almost suffering from several pollutants. In polluted Sea water, oxygen depletion, stress-induced mucus and laniellar lesions which support parasitic infestation on fishes, compounding an already stressful state (Overstreet and Howse, 1977). Fish parasites are nowadays considered as one of the most inviting fields of national research especially after the importance of fishes as a valuable source of protein, in which heavy infection may cause functional disturbances, retard growth, increase the susceptibility of fish for other infection and give the fish an unaesthetic appearance (Paperna, 1980 and Mahmoud, 1983).

During the last decade, parasites of marine and fresh water fishes in Egypt have been received much attention (Al-Bassel, 2004, 2006a, 2006b, 2006c; Al-Bassel and El-Damarany, 2001; Al-Bassel and Ohaida, 2007 and Al-Bassel et al., 2007) 
The mullets Mugil cephalus (Mugilidae) is a commercial marine fish in fish market. This species is omnivorous, feeds on plankton, thus it is more exposed to infection by trematodes than other marine fish, and is therefore selected for the present investigation. In Egypt, research has been done on mullets and its parasites (Al-Bassel, 1987, 1990). Libya was selected as the second area since M. cephalus is a common species throughout most of the year. Although some information on the parasites of marine fishes from other areas is known, differences in the parasite fauna of a widely distributed species can be expected with different geographical locations (Manter, 1955). The objective of this investigation was to study the natural parasite fauna of the mullets from one region of its distribution and to extend our knowledge about the prevalence and distribution of parasites in $M$. cephalus in the Mediterranean Sea in Libya.

\section{MATERIAL AND METHODS}

Smears from the skin, gill and fin surfaces are made on glass slides, air dried and fixed. Then, the whole body surface from just behind the gill cover till the end of the caudal fin was scraped using a scalpel blade or spatula. The scraped materials were then put on a glass slide, covered with a coverslip to be examined microscopically. In order to study the adhesive disc, positive smears were air-dried, then impregnated with $\mathrm{Ag} \mathrm{No}$ and irradiated with UV (Klein's method, 1958). For studying the recorded Myxosporea, length and width of cysts were measured then squashed for studying the spore morphology. Glycerin/gelatin mixture was used to preserve and to examine some details of the spores. Measurements of the fresh spores were taken using calibrated ocular micrometer on Zeiss photomicroscope.

Organs are opened by a pair of fine scissors and left in $0.7 \%$ saline solution. A hand lens and a binocular dissecting microscope were used for the helminthological examination. The collected worms were cleaned by washing them several times with isotonic saline solution. Relaxation, fixation, staining and mounting were carried out by the usual way.All parasites were figured and identified to the species level according to Yamaguti (1971). All measurements are in millimeters unless otherwise stated.

\section{RESULTS AND DISCUSSION}

\section{A) Protozoan infections:}

\section{1- Trichodina lepsii Lom, 1962 (Fig. 1)}

\section{Host: Mugil cephalus}

Location: gills

Locality: Lake Qarun, Egypt

This species was previously described in detail by Al-Bassel et al. (2007). This finding suggests that $M$. cephalus is the type host of this trichodinid and not $M$. auratus as proposed by Lom (1962)

\section{2- Trichodina puytoraci Lom, 1962 (Fig. 2)}

Host: $M$. cephalus

Location: gills

Locality: Lake Qarun, Egypt

This species was previously described in detail by Al-Bassel et al. (2007). This finding suggests that $M$. cephalus is the type host of this trichodinid and not $M$. auratus as proposed by Lom (1962). 
3-Trichodina batala Ali, 1996 (Fig. 3)

Host: $M$. cephalus

Location: gills

Locality: Lake Qarun, Egypt

This species was previously described in detail by Al-Bassel et al. (2007). This finding suggests that $M$. cephalus is the type host of this trichodinid

4- Myxobolus sp. (Fig. 4)

Host: $M$. cephalus

Location: body cavity and mesentery

Locality: Lake Qarun, Egypt

Description:

Only one $M$. cephalus was infected with one plasmodium of this myxosporean. The cyst was embedded in the mesenteries of the body cavity. Spores are oval to subspherical in frontal view. They measured $8.5 \pm 0.6(8.3-9.3) \mu \mathrm{m}$ in length and 7.2 $\pm 0.4(6.9-7.5) \mu \mathrm{m}$ in width. The polar capsules are pyriform, almost equal and measured $4.7 \pm 0.4(4.1-5.4) \times 2.5 \pm 0.1(2.0-2.9) \mu \mathrm{m}$. The polar filament showed about 5 turns almost perpendicular to the longitudinal axis of the polar capsules. Sporoplasm is binucleate and fills the all extracapsular space.

Discussion:

Review of myxosporean infecting the mullets indicated that 17 Myxobolus species is infecting this group of fishes. Only five Myxobolus species were found close in general shape to the present parasite. However, we refrain from final allocation of this parasite till further examination of mature spores.

B) Trematode infections:

5- Haplosplanchnus caudatus (Srivastava, 1939) (Fig. 5)

Host: M. cephalus

Location: intestines

Locality: Lake Qarun, Egypt

Description:

The body is Y-Shaped, with unequal arms, one end is the oral sucker, the second end is the protruded ventral sucker and the third end formed of the curved posterior end of the body which looks like a tail like structure. The body measures $1.55-2.87 \mathrm{~mm}$ in length and $0.64-0.77 \mathrm{~mm}$ in width. The oral sucker is oval, subterminal and measures $0.13-0.26$ long and $0.15-0.28$ wide. The ventral sucker is large club shaped found usually projected from the body but in some cases may be retracted into the body parenchyma; it measures $0.38-0.66$ long and $0.21-0.38$ wide. The prepharynx is short, 0.052 long. The pharynx is well developed, spherical in shape and measures $0.071-0.09$ long and $0.14-0.158$ wide. The oesophagus and the single simple straight intestinal caecum extend posteriorly to a short distance behind the level of the ventral sucker; both measure $0.58-0.69$ long and $0.06-0.22$ wide.

The single testis is oval in shape and lies at the posterior third of the body and measures $0.281-0.32$ long and $0.198-0.26$ wide. The vesicular seminalis is tubular, extending from anterior end of testis up to middle of caecum, measuring, 1.5 in length. Pars prostatica is oval and surrounded by a prostatical gland cells; it measures $0.16-0.18$ long. The genital atrium is tubular and measures $0.12-0.16$ long while the genital pore opens between the oral and the ventral sucker.

The ovary is oval in shape and lies at the right side, just anterior to testis measuring $0.22-0.23$ long and $0.17-0.21$ wide. The receptaculum seminis is oval in shape, and lies a little anterior-lateral to ovary. The vitelline follicles are few in 
number, located in 3-4 groups in the lateral field surrounding the ovary. The uterus extends from the anterior margin of the testes up to the level of the ventral sucker and it is full of mature, large and yellow colored eggs which measures $0.05-0.06$ long $0.03-0.038$ wide.

\section{Discussion:}

$H$. caudatus recorded in the present work was closely similar in all its morphological aspects to that mentioned by Al-Bassel (1987) except that the eggs in the present study were slightly larger in size. Specimens identified by Ezz El-Dien (1990) from Mugil species caught from Red Sea and Raef (1990) from Mugil species obtained from Mediterranean Sea were collectively larger in all measurements.

\section{6- Haplosplanchnus pachysomus (Eysenhardt, 1829) Looss, 1902 (Fig. 6)}

Host: $M$. cephalus

Location: intestines

Locality: Lake Qarun

Description:

The fresh worms are orange in color. They are fleshy parasites, fairly large and the body is somewhat fusiform more pointed posteriorly than anteriorly, the body measures $2.09-2.72$ long and $0.69-0.82$ wide. The oral sucker is triangular, muscular and subterminal, measuring $0.13-0.22$ long and $0.18-0.27$ wide while the ventral sucker is long, club-shaped, and it may be retracted into body parenchyma or projects prominently and measures $0.27-0.37$ long and $0.17-0.23$ wide. The prepharynx is very short measuring $0.01-0.02$ long. The pharynx is well developed and spherical in shape measuring $0.12-0.14$ long and $0.16-0.19$ wide. The oesophagus cannot be distinguished from the intestinal caecum which is a simple straight structure extending nearly to the middle of the body and measures $0.32-0.37$ long, ended with an oval sac at the middle of the body.

The testis is single, globular and oval in shape at the middle of the posterior half, measuring $0.21-0.24$ long and $0.19-0.21$ wide.

The genital atrium is tubular measuring $0.09-0.12$ long. The pars prostatica are elongate, surrounded by a large number of prostate gland cells and measures 0.11 -0.19 long. The genital pore lies between the oral and ventral sucker, but it is closer to the oral sucker and opens on a prominent papilla found between the two suckers. The nematode seminalis is long, tubular in shape extending from the anterior margin of testis up to oesophagus level and measures 0.07-0.09 long. The ovary is spherical in shape and lies anterior to the testis measuring $0.06-0.09$ long and $0.06-0.09$ wide. The vitelline follicles lies laterally near the ovary, each of these follicles leads to a fine duct which joins with other fine ducts to form a large vitelline duct which measures $0.15-0.17$ long and opens at the beginning of the uterus. The uterus is full of large and elongate eggs, which containing developing miracidia and each egg measures $0.04-0.06$ long and $0.02-0.03$ wide. The excretory vesicle is present and ends by a terminal execratory pore.

\section{Discussion:}

H. pachysomus was described from $M$. cephalus and M. cheloat_by Looss, 1902. In Egypt, $H$. pachysomus was first described from $M$. cephalus and $M$ ramada by Fischthal and Kuntz (1963). Then, it was redescribed from M. cephalus, Liza ramada, M. chelo and M. saliens from Lake Qarun by Al-Bassel (1987). Also, AlBassel (1990) described the same parasite in M. cephalus and L. ramada from Lake Edku.

The present material is similar to that described by Fishthal and Kuntz (1963), Al-Bassel (1987) and Eid (1997) in their main characteristics, but there are certain 
minor differences in body length and measurements of some internal organs.

7- Dicrogaster contractus (Looss, 1902) (Fig. 7)

Host: M. cephalus

Lacation: intestines

Locality: Lake Qarun, Egypt

Description:

It is an elongated worm measuring 0.74-0.84 in length and 0.17-2.15 in width. The body is mostly covered with spines. The oral sucker is sub terminal, oval in shape and measures $0.06-0.07 \times 0.07-0.08$. The prepharynx is short, $0.048-0.053$ in length. A well developed muscular pharynx is present; it is globular in shape and measures $0.05-0.06 \times 0.07-0.08$. The oesophagus is long, measuring $0.10-0.12 \mathrm{~mm}$ in length. The intestinal caecum is saccular in shape, it extends to the middle of the worm and measures $0.17-0.21$ in length and a maximum width of $0.03-0.04$, the ventral sucker is oval in shape and situated nearly above the middle of the body shifting to either right or left side of the body, it measures 0.07-0.08 x 0.07-0.09.

The testis is globular in shape, located at the middle of the posterior half of the body, each measures $0.066-0.072 \times 0.076-0.082$. The cirrus pouch is well developed, pre-acetabular in position and ovoid in shape, it measures $0.17-0.18 \times 0.10-12$. The cirrus pouch contains prostatic gland cells, a hermaphroditic duct and internal seminal vesicle. The external seminal vesicle is oval in shape and measures 0.05-0.06 x 0.040.05 . The ovary is nearly spherical, smaller than testes and postacetabular in position and anterior to the testes, it measures $0.05-0.06 \times 0.05-0.06$. The vitelline glands are in 2 groups mostly at one lateral side between the testis and the caecal end. The excretory vesicle is spherical in shape and opens at the posterior end with a terminal excretory pore. The eggs are oval in shape and measures 0.036-0.042 x 0.018-0.026.

\section{Discussion:}

In the present work, $D$. contractus was identical in its morphological aspects to Looss (1902) specimens except for minor differences in certain measurements. In the redescription recorded by Fares and Maillard (1974), the excretory vesicle was yshaped while in the present material it was spherical, a feature which has been recorded by Looss (1902). Al-Bassel (1987) recorded the parasite but his measurements were smaller (total body length 0.49-0.65) than that recorded in the present work (0.74-0.84). Hence, other body organs were also smaller than that obtained in the present work, including prepharynx and intestinal caecum. It was important to notice that the genus Dicrogaster has been originally reported from fishes in the Mediterranean Sea (Looss, 1902). This genus has apparently reached Fayoum area with Mugil spp. which have been transferred to water bodies in Fayoum (Khalil, 1978). Al-Bassel (1987) recorded the parasite from Lake Wadi Al-Rayan in Fayoum Province and not from Lake Qarun, although specimens of. D. contractus collected from $M$. cephalus in the present work, collected from Lake Qarun.

\section{8- Lecithobotrys putrescens Looss, 1902 (Fig. 8)}

Host: $M$. cephalus

Location: intestines

Locality: Lake Qarun, Egypt

Description:

The worms are grayish white in color, elongated and tapering anteriorly, measuring 1.115 in length and 0.551 in body width. The whole body surface of the worm is covered by spines which are easily shed. The oral sucker is sub-terminal and relatively larger than the ventral sucker measuring $0.106 \times 0.108$. The ventral sucker measures $0.092 \times 0.098$. The pharynx is large, elongated in shape, measuring 0.088 in 
length and 0.044 in width; the prepharynx is short being 0.062 in length while the oesophagus is 0.070 in length. The intestinal caeca are tubular in shape and extending back far beyond the ventral sucker to the posterior end of testis, it is short (0.230) in length. The bifurcation of the intestine occurs dorsal to the ventral sucker.

The testis is located not far behind the ventral sucker and it is nearly rounded measuring $0.074 \times 0.072$. The cirrus pouch is egg-shaped, 0.128 long and 0.052 wide. The ovary is median, spherical in shape, it lies behind the testis; it is smaller than the testis measuring $0.056 \mathrm{~mm}$ long and 0.048 wide. The vitelline glands are formed of two irregular shaped follicles in each laterally. The eggs are numerous, each measures $0.044 \times 0.030$ the excretory vesicle is large and saccular opened by the main excretory pore which is sub-terminal and lies in a large depression in the posterior extremity of the worm.

\section{Discussion:}

The morphological characters of $L$. putrescens under investigation agree with that described by Al-Bassel (1987) although the measurements of the ovary and testis in the present specimens were smaller in size, a feature which may be due to incompletely grown parasite obtained in the present work.

\section{9- Vitellibaculum girelia Montgomery, 1957 (Fig. 9)}

\section{Host: $M$. cephalus \\ Location: intestines \\ Locality: Missurata, Libya \\ Description:}

The entire worm is oval, measuring $1.25-1.26$ in length and 6.22-6.29 in width. The oral sucker is terminal and measures $0.04-0.05 \times 0.07-0.08$. Prepharynx is long, 0.011-0.018 in length. A well developed muscular pharynx is present; it is globular in shape and measures $0.14-0.15$ long and 0.14- 0.16 wide. The oesophagus is absent. The intestinal caecum is tubular in shape and measures $0.18-0.21$ in length. The ventral sucker is larger than the oral sucker, it measures $0.07-0.08 \times 0.07-0.09$.

The testes are tandom in position, located at the middle of the posterior half of the body, each measures $0.076-0.082 \times 0.075-0.081$. The cirrus pouch is well developed, pre-acetabular in position, it measures $0.167-0.178 \times 0.104 .119$. The ovary is nearly spherical, smaller than testes and anterior to the testes, it measures 0.053 $0.056 \times 0.054-0.057$. The vitelline glands are scattered in posterior half of the body. The excretory vesicle is y-shaped and opens at the posterior end with a terminal excretory pore. The eggs are oval in shape and measures $0.035-0.041 \times 0.018-0.025$.

\section{Discussion:}

This species was originally described by Montgomery (1957) from Girelia uigricans fish from California. The present work fully agrees with the original description, but the present description represents new host and new locality record.

\section{0- Lecithocladium excisum (Rud, 1819) Luhe, 1901(Fig. 10)}

\section{Host: $M$. cephalus}

Location: intestines

Locality: Missurata, Libya

Description:

The entire worm is elongate with tail like structure, measuring $1.87-1.97$ in length and 0.34-0.37 in width. The oral sucker is funnel-shaped and measures 0.063$0.064 \times 0.098-0.099$. Pharynx is well developed and measures 0.12-0.16 long and $0.18-0.19$ wide. The oesophagus is short. The intestinal caecum is tubular in shape and measures $0.34-0.35$ in length. The ventral sucker measures $0.088-0.085 \times 0.062$ 0.084 . 
The testes are small, located at the middle of the body, each measures 0.033$0.034 \times 0.030-0.032$. The ovary is nearly spherical, larger than testes and posterior to testes, it measures $0.055-0.058 \times 0.057-0.059$. The vitelline glands tubular and consists of 7 covoluted posterior to ovary. The excretory vesicle is elongate, tubular in shape and opens at the posterior end with a terminal excretory pore. The eggs are small and measures $0.024-0.025 \times 0.012-0.013$.

\section{Discussion:}

This species was originally described by Rud (1819) and Luhe (1901) from Scombrus scombrus fish from the Mediterranean. The present work fully agrees with the original description, but the present description represents new host and new locality record.

\section{C) Acanthocephala infections:}

\section{1- Neoechinorhynchus sp. (Figs 11, 12, 13)}

Host: $M$. cephalus

Location: intestines

Locality: Lake Qarun, Egypt

Description:

The following description was based on 12 specimens collected from the intestines of M. cephalus caught from Lake Qarun. The body of the worm is elongated and cylindrical with truncate ends (Fig. 11). The body is measuring $7.5-13.15$ long and $0.57-0.82$ wide. The body is covered with a thin tegument followed by a much thicker hiypodermis. The proboscis is small and globular, measuring $0.26-0.29$ long and $0.132-0.151$ wide. The proboscis has 18 hooks arranged in three spiral rows, each row has six hooks, each hook is provided with root processes (Fig.12). The hooks of the first row are the largest measuring $0.17-0.185$ long for each one. The hooks of the second rows measuring $0.068-0.072$ long while the hooks of the third row measuring $0.042-0.053$ long for each (Fig. 12). The proboscis is keeping in the proboscis receptacle when invaginated, this proboscis receptacle measuring $0.72-$ 0.98 long and $0.14-0.29$ wide. Three or four giant nuclei are present in the dorsal side while four are present on the ventral side. The two lemnisci are unequal, the larger measuring $0.92-1.1$ long while the smaller measuring $0.61-0.68$ long. There is a few number of ovarian balls represented the ovary (Fig. 13). The uterine ball is oval measuring $0.09-0.22$ long and $0.05-0.11$ wide followed by a short uterus opens into vagina and finally opens posteriorly by the female gono-pore.

\section{Discussion:}

The worm described above evidently belongs to the genus Neoechinorhynchus Hamann, 1892. The two related species are the Neoechinorhynchus ichthyobori Saoud et aI., 1974 which was described from fresh water fish Ichthyoborus besse caught from the white Nile at Jebel Al-Awliya in Sudan and also Neoechinorhynchus sp, which was redescribed by Al-Bassel (1990) from M. cephalus caught from lake Edku. It is worth to mention that the present material was reported from a new locality.

\section{REFERENCES}

Al-Bassel, D.A.M.L. (1987): A general survey on the helminth parasites of some fish from Fayoum governorate, Arab Republic of Egypt. M. Sc. Thesis, Faculty of Science, Ain-Shams Univ., Cairo, Egypt.

Al-Bassel, D.H.M. (1990): Studies on the helminth parasites of some fishes from some inland water in Egypt. Ph. D. Thesis Fac. Sci. Cairo Univ., Beni Suef branch. Egypt. 
Al-Bassel, D.A. (2004): Surface ultrastructure of the scolex of the postlarva of Tentacularia bicolor (Cestoda: Trypanorhyncha) J. Egypt. Ger. Soc. Zool. (44D): 53-67.

Al-Bassel, D.A. (2006a): Scanning electron microscopic studies on Contracaecum magnipapillatum (Nematoda: Anisakidae) from cormorants in Wadi AlRaiyan lake area, Fayoum, Egypt. J.Egypt.Ger.Soc.Zool, (49D): 39-48.

Al-Bassel, D.A. (2006b): Surface topography of Hysterothylacium winteri Torres and Soto, 2004 (Nematoda: Anisakidae) from Boops boops marine fishes from Egypt. Egypt. J. Aquat. Biol. \& Fish., 10(1): 125-138.

Al-Bassel, D.A. (2006c): Studies on Phyllobothrium lactuca (Cestoda: Phyllobothriidae) and Philometra salgadoi (Nematoda: Philometridae) parasitizing Boops boops from the Mediterranean Sea, Egypt. J. Egypt. Soc. Parasitol., 35: 1163-1172.

Al-Bassel, D.A. and El-Damarany, M. (2001): On Infundibulostomum anisotremi and Hysterolecitha sogandaresi (Digenea: Trematoda) redescribed from the fish Mullus surmuletus from the Mediterranean Sea in Libya. J. Egypt. Ger. Soc. Zool., 36(D): 141-151.

Al-Bassel, D.A.H and Ohaida, A.-S.M. (2007): Light and TEM studies on the gills of tuna infecting with Allodidymozoon pharyngi (Didymozoid trematodes) from Libya. J. Egypt. Ger. Soc. Zool, 52A :117-129.

Al-Bassel, D.A., Abdel-Azim S. A., Marwa S. A. (2007): Trichodinid ectoparasites (Ciliophora: Peritrichia) of Mugil cephalus Linnaeus, 1758 from Lake Qarun, Egypt . Egypt. J.Aqut.Biol. \&Fish., 11: 13-26.

Ali, M.A. (1996): Biological studies on trichodinids and myxosporeans infecting saline- and freshwater lakes in Egypt. Ph. D. thesis, Fac. Sci., Cairo Univ., Egypt.

Eid, A.S. (1997): Studies on parasites of the Egyptian cultured fish M. Sc. Thesis, Fac.Vet. Med. Cairo Univ.

Ezz-EL-Dien, M.N. (1990): Some studies on the helminth parasites of marine water fishes in Suez Canal area. M. V. Sc. Thesis, Fac. Vet. Med. Suez Canal Univ. Egypt.

Fares, A. and Maillard, C. (1974): Research on some Haploporidae (Trematoda) parasites of the mullet. Z. Parasitenk., 45: 11-43.

Fischthal, J.H. and Kuntz, R.E. (1963): Trematodes parasites of fishes from Egypt.Part II. Six new Hemiuridae. Proc. Helminth. Soc. Wash. 30: 78-91.

Khalil, M.T. (1978): Ecological and biological studies on zooplankton of Lake Qarun and Wadi El-Raiyan with special reference to crustacean. M.Sc. thesis, Fac. Science, Ain-Shams Univ., Egypt.

Klein, B.M. (1958): The dry silver method and its proper use. J. Protozool., 5: 99-103.

Lom, J. (1962): Trichodinid ciliates from fishes of the Rumanian Black Sea Coast. Parasitology, 52:49-61.

Looss, A. (1902): Die Distomen unterfamilie der Haploporinae. Arch. Parasit., 6: 129.143.

Luhe, M. (1901): Uber Hemiuriden. Zool. Anz., 24: 394- 403.

Mahmoud, N.A. (1983): Parasitic infestations of some native species of fishes in Cairo markets with special reference to parasites transmissible to man and animals. M. V. Sc. Thesis, Fac. Vet. Med. Cairo Univ. Egypt.

Manter, H.W. (1955): The Status of the Trematodes genus Deradena Linton with a description of six species of Haplosplanchnus Looss (1902) (Trematoda). Rabot. Gelmint Skrjabin (Skrjabin jubilee Voi), 381-387. 
Marwa T.M.A. (2008): Host - Parasite relationship of some fish parasites from Fayoum, Egypt. M.Sc. Thesis, Fac. Sci. Fayoum University. Egypt.

Meshal A.H. (1973): Water and salt budget of Lake Qarun, Fayoum, Egypt. Ph.D. thesis, Alexandria University, Egypt.

Montgomery, R.E. (1957): Studies on digenetic trematodes from marine fishes of La Jolla, California. Diss. Abstr. 16: 25-64.

Overstreet R.M. and Howse H.D. (1977): Some parasites and diseases of estuarine fishes in polluted habitats of Mississ Armals of the New York Academy of Science, 298 ed. H.F.

Paperna, I. (1980): Parasites infections and diseases of fish of Africa. Committee for inland fisheries of Africa. CIFA Technical papers 51-62.

Raef, A.M. (1990): Some studies on the helminth parasites of marine fish. M. V. Sc. Thesis, Fac. Vet. Med. Zag. Univ. Egypt.

Rudolphi,C.A. (1819): Entozoorum synopsis cui accedunt mantissa duplex et indices locupletissimi. Berol.811pp.Saoud, M.F.A., El-Naffar, M.K. and AbuSinna, H. (1974): Neoechinorhynchus ichthyobori n.sp. (Acanthocephala: Neoechinorhynchidae) from a freshwater fish in the Sudan. Bull. Zool. Soc. Egypt, 26: 89-93.

Yamaguti, S. (1971): Synopsis of Digenetic trematodes of vertebrates. Tokyo, Keigaku Publ.

Abbreviations

\begin{tabular}{|l|l|l|}
\hline & Full name & Abbreviation \\
\hline $\mathbf{1}$ & Mugil & M. \\
\hline $\mathbf{2}$ & Haplosplanchnus & H. \\
\hline $\mathbf{3}$ & Lecithobotrys & L. \\
\hline $\mathbf{4}$ & Dicrogaster & D. \\
\hline $\mathbf{5}$ & Trichodina & $T$. \\
\hline $\mathbf{6}$ & Vitellibaculum & V. \\
\hline $\mathbf{7}$ & Lecithocladium & Le. \\
\hline
\end{tabular}



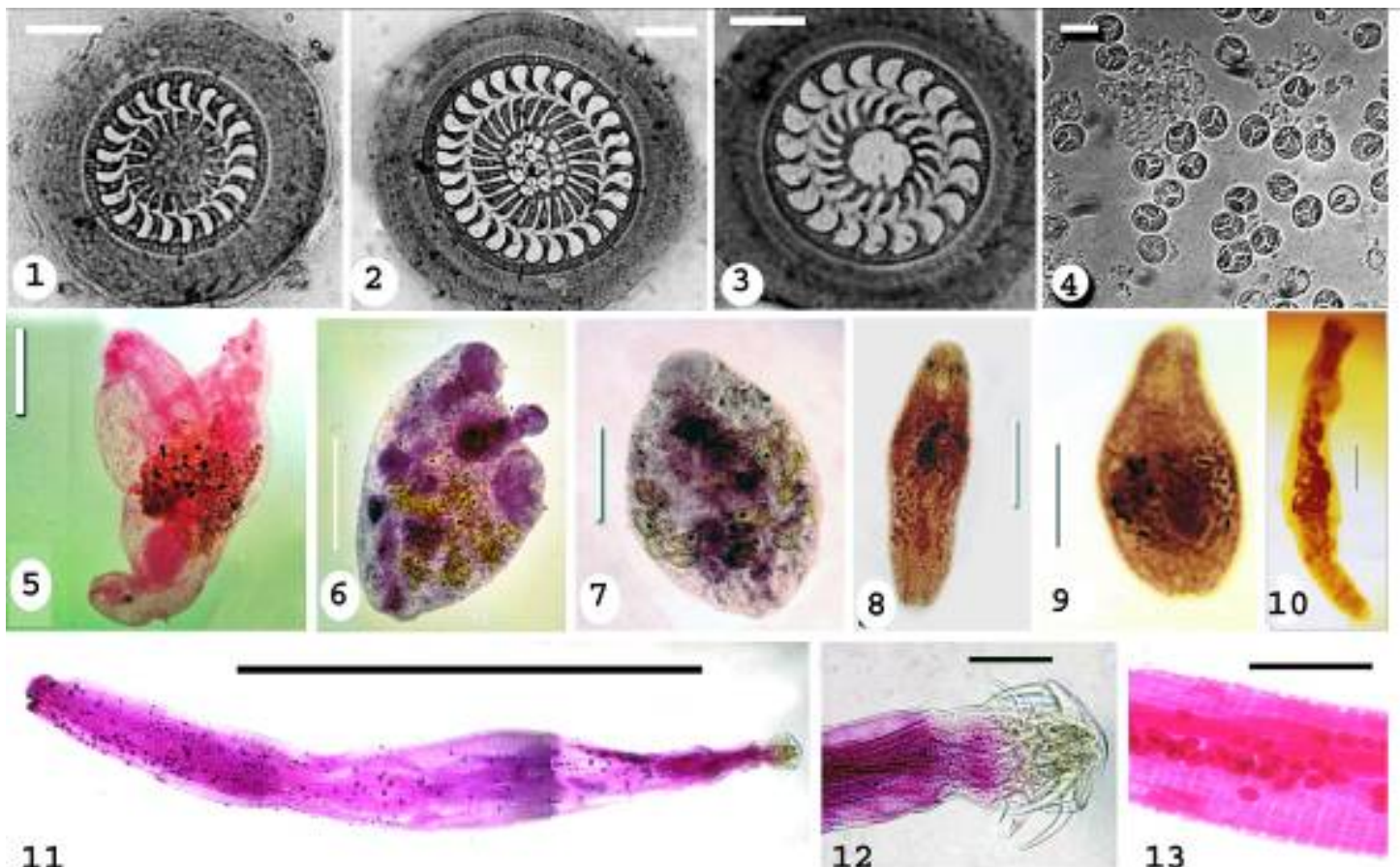

10

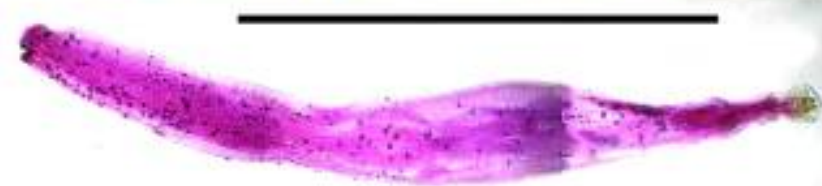

11

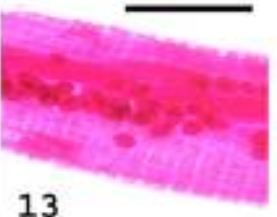

Fig. 1- Light micrograph showing T. lepsii (S.bar $10 \mu \mathrm{m}$ ). Fig. 2- Light micrograph showing T. puytoracii (S.bar $10 \mu \mathrm{m}$ ). Fig. 3- Light micrograph showing T. batala (S.bar $10 \mu \mathrm{m})$. Fig. 4- Light micrograph showing Myxobolus spp. (S.bar $10 \mu \mathrm{m}$ ). (After Al-Bassel, et al. 2007). Fig. 5- Light micrograph showing $H$. caudatus (S .bar $0.4 \mathrm{~mm}$ ), Fig. 6- Light micrograph showing $H$. pachysomus (S.bar $0.4 \mathrm{~mm}$ ). Fig.7- Light micrograph showing D. contractus(S .bar $0.2 \mathrm{~mm}$ ). Fig. 8- Light micrograph showing Lecithbotrys putrescens (S.bar $0.3 \mathrm{~mm}$ ). Fig. 9- Light micrograph showing V. girelia (S.bar $0.5 \mathrm{~mm}$ ). Fig. 10- Light micrograph showing Le. excisum (S.bar $0.3 \mathrm{~mm}$ ). Fig. 11-13: Light micrographs showing Neoechinorhynchus sp. 11. Entire worm (S.bar $5 \mathrm{~mm}$ ). 12- Proboscis (S.bar $0.4 \mathrm{~mm}$ ). 13- Female middle part (S. bar 0.5). (After Marwa T.M. A., 2008) 


\section{ARABIC SUMMARY}

\section{مسح على طقيليات اسماك البورى من مصر وليبيا \\ ديهوم عبد الحميد الباسل 1 عبد الناصر حسين2

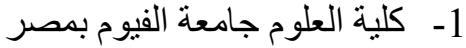 \\ 2- كلية العلوم بقنا جامعة جنوب الو ادى الفي بمصر}

منطقتين مختلفتين هما بحيرة قارون بالفيوم بمصر وسوق الاسماك بمصر اتة بليبيا ثم اختيار هما لغرض

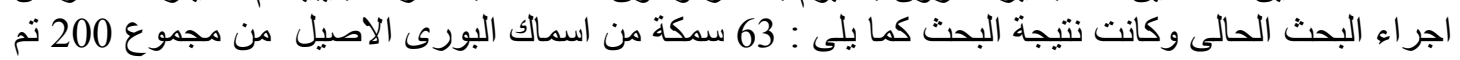

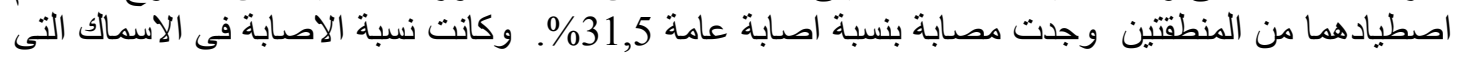

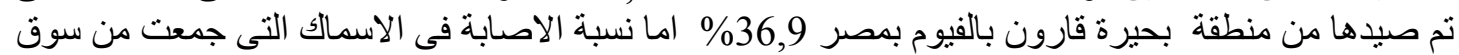

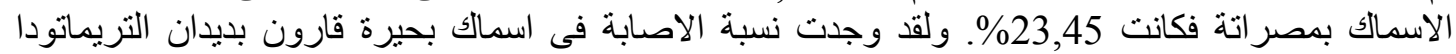

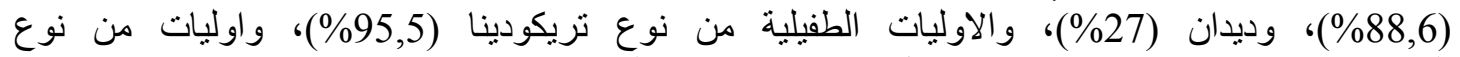

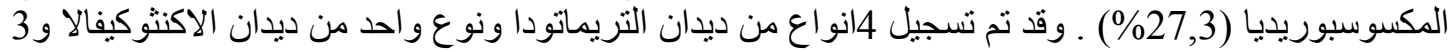

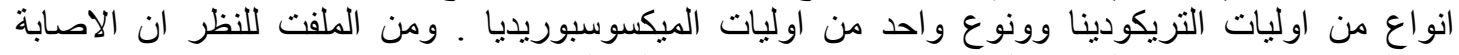

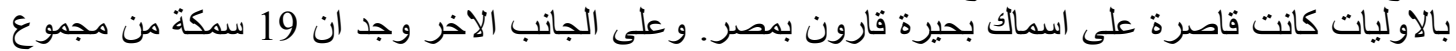

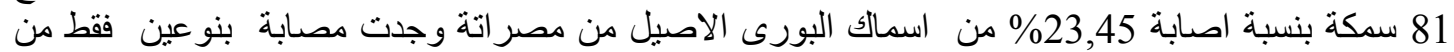

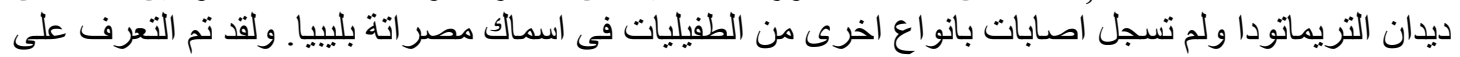

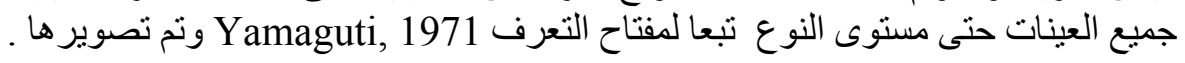

